\title{
FACTORS AFFECTING PATIENT SATISFACTION IN JKN SYSTEM: STUDY ON PATIENT CHARACTERISTICS, JKN SERVICES, AND PHARMACY SERVICES
}

\begin{abstract}
Satibi $^{1} *$, Diah Ayu $\mathbf{P}^{2}$, Sendy Stefanie L. ${ }^{3}$, Putu Dyana C. ${ }^{3}$
1Faculty of Pharmacy, Universitas Gadjah Mada, Yogyakarta, 55281

Indonesia

2Faculty of Medicine, Universitas Gadjah Mada, Yogyakarta, 55281 Indonesia

${ }^{3}$ Post graduate student, Faculty of Pharmacy, Universitas Gadjah Mada. Yogyakarta, Indonesia, 55281

Submitted: $16-07-2015$

Revised: $12-08-2015$

Accepted: $11-09-2015$

*Corresponding author Satibi

Email:

satibi@ugm.ac.id
\end{abstract}

\section{INTRODUCTION}

National Health Insurance (JKN) held in Indonesia from January 1, 2014 as health protection for all Indonesian people so that people obtain health care benefits and protection to fulfill their basic health needs. $\mathrm{JKN}$ is organized by BPJS Kesehatan. It charge of implementing cooperation agreements with existing health facilities throughout Indonesia so that the implement-tation of health insurance can be implemented nationally (Republik Indonesia, 2011).

The implementation of national health insurance can improve the health of the nation of Indonesia. Therefore it is necessary to monitor and evaluate periodically of the JKN system. Indicator that can be used to measure the success rate of the system is the level of patient satisfaction. Patient satisfaction with JKN system will affect the viability and effectiveness of the system that has been running (Pohan, 2007).

According to Hall and Dornan (1990) factors influencing patient satisfaction among other characteristics of the patient, where the different patient characteristics can provide different behavioral responses satisfied in each individual. According Schoenfelder et al. (2010), patient characteristics significantly related to patient satisfaction were age, gender, social 
status, and education. Age and education which have a strong relationship with patient satisfaction.

The other hand, the satisfaction of the patient was also influenced by JKN service which includes the premium paid, information services and membership. Premiums paid includes the payment procedure and amount of the premium paid, which is the determining factor for patient satisfaction with health insurance system (Akinci and Sinay, 2003). Research in Ghana showed that $97.9 \%$ of people in Ghana do not understand and do not obtain information about the mechanism of the insurance system so that they were not satisfied with the health insurance system in Ghana (Agyei-Baffour, et al., 2013).

Patient satisfaction was also influenced by the health facility services, one of which is a pharmacy services. Pharmacy services include drug availability, service time, and the provision of drug information have a positive effect on patient satisfaction and loyalty (Trimurthy, 2009). According to data in BPJS Kesehatan, some of the complaints such as: unavailability of drugs in health facilities or empty medicine, limited supply of drugs for chronic diseases, there are drugs that have not been included in the national formulary so that patients have to pay additional costs of drugs, and the limited provision of relevant information JKN and drugs are given.

The purpose of this studies to analyze the factors that affect patient satisfaction on JKN system, including patient characteristics, JKN services and pharmacy services. Studies performed on outpatients at the primary health facilities in Sleman, Bantul and Yogyakarta. This study is expected to provide input to the Government, health facilities, and BPJS Kesehatan to improve the system in providing better health, the services to the community and improve existing JKN system.

\section{MATERIAL AND METHODS Study design}

This study was conducted with analytic cross sectional design. Data were taken quantitatively by using questionnaires. Respondents were asked to fill out a questionnaire and then equipped with qualitative data from interviews to deepen the findings in the field and generate a comprehensive understanding of the phenomenon under investigation in the field.

\section{Location and subject}

The study was conducted in primary health facilities ie Primary health centers and clinics in Sleman, Bantul, and the city of Yogyakarta in 2014. The number of health facilities was determined by random sampling obtained by 55 primary health facilities. The sampling method used to determine the amount of the sample was purposive sampling. The sampling method used the formula sample regression analysis and obtained 300 respondents, which is then divided into 150 respondents to measure the effect of JKN services to patient satisfaction and 150 respondents to measure the effect of pharmacy services to patient satisfaction. Respondents were distributed proportionally to each primary health facilities were selected.

The patient were outpatient at the Primary Health Facilities (Puskesmas and Health Clinic) in Sleman, Bantul, Yogyakarta city and over the age of 18 years, all subject selected were JKN participants and not a participant of any other health social assurance; patients willing to participate in this study by completing a questionnaire; cooperative and can communicate well; and have a minimum of 2 times visit to primary health facilities since the enactment of JKN system.

\section{instruments}

The study instruments used were two questionnaires, each of which contains questions about the characteristic of patients, a statement with a structured answers regarding various aspects of JKN services for the first questionnaire and pharmacy services in JKN era for a second questionnaire as well as patient satisfaction, and the last was an open question regarding patient complaints and suggestions. The statement in the questionnaire prepared by the legislation in force and practical guidance related to national health insurance system published by BPJS Kesehatan.

The questionnaire validity test with Pearson Product Moment method with a valid criteria when the count $r>0.361$ and reliability testing with Cronbach's Alpha method with 
reliable criteria when Cronbach's Alpha value> 0.6. For the first questionnaire, of 32 items statements regarding JKN services and patient satisfaction with the JKN system as much as 9 items declared invalid question so removed from the questionnaire. For the second questionnaire, of 34 items statements regarding pharmacy services and patient satisfaction the JKN system as much as 9 items declared invalid question so removed from the questionnaire.

\section{Data analysis}

The unit analysis is primary health facilities. For statistical analysis of the characteristics of the sample used descriptive statistical analysis, where the analysis is used to describe the overall study sample data. Then, to determine the influence of each group characteristics of patients with patient satisfaction used Chi-Square test, which is considered to have a significant effect if the value of $\mathrm{p}<0.05$. To see the effect of $\mathrm{JKN}$ services and pharmacy services to client satisfaction used linear regression, which is considered to have a significant effect if the value of $\mathrm{p}<0.05$

\section{RESULTS AND DISCUSSION Descriptive analysis of patient characteristics}

This study uses 300 outpatients in primary health facilities in Sleman, Bantul and Yogyakarta.

Descriptive analysis showed most respondents age groups there are in the age range $48-62$ years as much as $30.33 \%$. These data indicate that the majority of participants BPJS who use health services are participants aged 48-62 years. According Sumaryanti (2000), the age group most widely used health care services one of which is the elderly, in addition to children and women at the age of parenting. In addition, the older the respondents tendency for more frequent users of health services will be higher.

Respondents with female sex more than male, amounting to $64.33 \%$. Consumption and one's tastes are formed by gender, where there are certain differences between male and female. Female's groups usually use the services or products of health services more than male's group. According to a national survey in the US showed a conclusion that female have an important role as decision makers in health care, not only for herself but also for her family (Kotler, et al., 2008).

Characteristics of recent education has the highest proportion of respondents who are high school with the percentage of $31.33 \%$. This illustrate that the majority of participants BPJS last education is high at high school. A person's level of education affects one's perspective in the use of health services. High level of education allows a person to process the received information into a certain attitude. A person who has a low education will have a low stance also in the maintenance of health (Notoatmodjo, 2010).

Most respondents work characteristics are as housewives, farmers, or does not work, with the percentage of $35.33 \%$. According to the Central Bureau of Statistics Province DI Yogyakarta, the employment status of a person in a position of doing the job in a business unit / activity is used as an indicator to describe the formal and informal activities. In 2014 the labor force working in the formal activities in DI Yogyakarta with $45.91 \%$ and working in the informal activity of $54.09 \%$. Then respondents were obtained in the study were mostly work in the informal sector are as farmers, housewives, as well as self-employed.

Furthermore, the income data it can be seen that the first rank of $34.33 \%$ is the group of respondents who have an income of 1-2 million per month. Minimum Wage District / City of Yogyakarta in 2014 is an average of 1.1 million per month so that the average income of residents of Yogyakarta ranged between 1-2 million dollars per month. In addition, the majority of respondents in this study had a job as a self-employed (small traders, rickshaw drivers, craft businesses), farmers, housewives and so their income is not too high.

At the highest percentage of membership status data that equal to $44.33 \%$ of the respondents are beneficiaries dues. According to data from BPJS Kesehatan 2014, the number of participants receiving tuition assistance reached 1.572.154 inhabitants, while the number of civil servants / pensioners who have registered as participants BPJS as 390.346 inhabitants and the number of participants who registered through a business entity / company 
as much as 149.194 inhabitants. From these data it appears that indeed most of the participants BPJS in Yogyakarta is a participant receiving tuition assistance. In addition, because of the health insurance paid by the government as a whole led to high public response to use of health care for itself.

\section{Effect analysis of patient characteristics to patient satisfaction}

This analysis is used to prove the existence of the influence of patient characteristics on patient satisfaction in the primary health facilities related to the implementation of JKN system. Data were analyzed using Chi-Square with the limit values of significance (p) of 0.05 .

In the analysis of the effect of age differences in patient satisfaction was found that both young age to old age tend to feel satisfied with the service JKN. This means there is no significant relationship between age and the level of patient satisfaction. According Manurung (2010), no significant difference between age and the level of patient satisfaction. All ages both young and old feel satisfied with JKN system that has been running, although there is a tendency of patients with older age tend to feel satisfied with the services provided.

In the analysis of the influence of gender differences in patient satisfaction obtained results that there is no effect of gender differences on satisfaction. Both male and female have the same level of satisfaction of the system JKN, but respondents with female gender is easier to make a complaint compared with male. The majority of female respondents are mothers who have an important role as decision makers in health care, not only for herselves but also for her family (Manurung, 2010).

In the analysis of the effect of educational differences in patient satisfaction obtained that at the higher education level, respondents were dissatisfied more. Each behavior can be satisfied because of influencing by intelligence or knowledge that can be acquired through education. Level of education will be influential in providing a more rational response to the information that came and would think the extent to which benefits may be derived from the idea (Bauk, et al., 2013).

In the analysis of the effect of different jobs with patient satisfaction was found that the average student / students, self-employed, retired, private employees, as well as housewives or respondents who do not work tend to be satisfied with the service JKN. However, the majority of civil servants (22 of 25) are not satisfied with the system running $\mathrm{JKN}$. This is because there is a difference between the current service system into Askes (health insurance) to become participants JKN. This adjustment led to respondents who worked as civil servants are not satisfied with the system running. From the results of analysis show that there is a significant relationship between job satisfaction, where respondents with lower middle jobs tend to be satisfied with the health care system in the facility (Hall and Dornan, 1990).

In the analysis of the effect of differences in income with patient satisfaction showed that most respondents with incomes of small ( $<1$ million) to moderate income (2-3 million) were satisfied with the service JKN. However, some respondents with high incomes ( $>3$ million) are not satisfied with the service JKN given. From the results of analysis show that there is a significant relationship between income and satisfaction. According Hidayati, et al., (2014) the higher the income, the higher the patient's demand for health services and systems JKN running.

In the analysis of the effect of different membership status with patient satisfaction in mind that there is a significant relationship between membership status with satisfaction. According to Budiman et al., (2010) there are differences in satisfaction between patients who paid the fee independently with who paid by the government or agency work. Respondents that the fee was paid by the government tend to feel satisfied with the existing system because without paying any fees they can receive medical care. 
Table I. Patient Characteristics

\begin{tabular}{|c|c|c|c|c|}
\hline \multirow{2}{*}{ No. } & \multirow{2}{*}{ Characteristics } & \multirow{2}{*}{ Parameter } & \multicolumn{2}{|c|}{ Quantity of Participants } \\
\hline & & & $\mathrm{n}$ & $\%$ \\
\hline \multirow{4}{*}{1} & \multirow{4}{*}{ Age } & $18-32$ years & 62 & 20.67 \\
\hline & & $33-47$ years & 85 & 28.33 \\
\hline & & $48-62$ years & 91 & 30.33 \\
\hline & & $>62$ years & 62 & 20.67 \\
\hline \multirow{2}{*}{2} & \multirow{2}{*}{ Gender } & Male & 107 & 35.67 \\
\hline & & Female & 193 & 64.33 \\
\hline \multirow{5}{*}{3} & \multirow{5}{*}{ Education } & Elementary school & 36 & 12.00 \\
\hline & & Pre elementary school & 56 & 18.67 \\
\hline & & High school & 94 & 31.33 \\
\hline & & Diploma/graduate & 78 & 26.00 \\
\hline & & Post graduate & 36 & 12.00 \\
\hline \multirow{6}{*}{4} & \multirow{6}{*}{ employment } & Student & 15 & 5.00 \\
\hline & & Entrepreneur & 67 & 22.33 \\
\hline & & Civil servant & 47 & 15.67 \\
\hline & & Retired & 26 & 8.67 \\
\hline & & Private employees & 39 & 13.00 \\
\hline & & Etc & 106 & 35.33 \\
\hline \multirow{5}{*}{5} & \multirow{5}{*}{ Income } & $<1$ million rupiah & 99 & 33.00 \\
\hline & & 1-2 million rupiah & 103 & 34.33 \\
\hline & & 2-3 million rupiah & 51 & 17.00 \\
\hline & & 3-4 million rupiah & 29 & 9.67 \\
\hline & & $>4$ million rupiah & 18 & 6.00 \\
\hline \multirow{3}{*}{6} & \multirow{3}{*}{$\begin{array}{c}\text { Membership } \\
\text { status }\end{array}$} & Beneficiaries dues & 133 & 44.33 \\
\hline & & Worker wage earners & 98 & 32.67 \\
\hline & & Worker not wage earners & 69 & 23.00 \\
\hline
\end{tabular}

Effect Analysis of JKN Services to Patient Satisfaction

To see the effect of JKN services to patient satisfaction used linear regression analysis. JKN services said to have a significant effect on satisfaction if it has a sig $(p)<0.05$.

In the analysis of the effect of the premium with patient satisfaction was found that there are significant differences in premium paid with satisfaction. According Akinci and Sinay (2003), the most prominent factors of patient satisfaction with the health care system is the amount of insurance premium and payment procedures. The greater the premium paid, the greater the demands of service expected by the participants so that the satisfaction of participants who pay higher premiums to be difficult to achieve. In JKN system, health care differences based on premiums paid only in the inpatient ward facilities. Treatments and drugs given to each class of the same treatment even though premiums are paid different. This is why the participants feel the satisfaction of different based on his experience in acquiring health services and the amount of the premium paid (Agyei-Baffour et al., 2013).

Information services provided are also closely related to the satisfaction of the participants. When participants do not understand or get the right information about the system that applied, the participants feel will be difficult to use or benefit from a system that led to the dissatisfaction of participants to the system (Akinci and Sinay, 2003). According Agyei-Baffour et al. (2013) and Mulupi (2013), lack of socialization and access to information are causing unsatisfaction with the running health system. People's desirement to take advantage of health insurance is low because it does not have enough information. 
Table II. Effect of Patient Characteristics to Patient Satisfaction

\begin{tabular}{|c|c|c|c|}
\hline $\begin{array}{l}\text { Dependent } \\
\text { Variabel }\end{array}$ & $\begin{array}{l}\text { Independent } \\
\text { Variabel }\end{array}$ & $\mathrm{p}$ & Result \\
\hline \multirow{6}{*}{$\begin{array}{l}\text { Patient } \\
\text { satisfaction }\end{array}$} & Age & 0.767 & $\begin{array}{l}>0,05 \text {; no significant difference between } \\
\text { age and satisfaction }\end{array}$ \\
\hline & Gender & 0.074 & $\begin{array}{l}>0,05 \text {; no significant difference between } \\
\text { gender and satisfaction }\end{array}$ \\
\hline & Education & 0.020 & $\begin{array}{l}<0,05 ; \text { a significant difference between } \\
\text { education and satisfaction }\end{array}$ \\
\hline & Employment & 0.001 & $\begin{array}{l}<0,05 \text {; a significant difference between } \\
\text { employment and satisfaction }\end{array}$ \\
\hline & Income & 0.000 & $\begin{array}{l}<0,05 ; \text { a significant difference between } \\
\text { income and satisfaction }\end{array}$ \\
\hline & Membership status & 0.005 & $\begin{array}{l}<0,05 \text {; a significant difference between } \\
\text { membership status and satisfaction }\end{array}$ \\
\hline
\end{tabular}

Tabel III. Effect of JKN Services to Patient Satisfaction

\begin{tabular}{|c|c|c|c|}
\hline $\begin{array}{c}\text { Dependent } \\
\text { Variable }\end{array}$ & $\begin{array}{l}\text { Independent } \\
\text { Variable }\end{array}$ & $\mathrm{p}$ & Result \\
\hline \multirow{4}{*}{$\begin{array}{l}\text { Patient } \\
\text { Satisfaction }\end{array}$} & Premium paid & 0.017 & $\begin{array}{l}<0,05 \text {; a significant difference between premium } \\
\text { paid and satisfaction }\end{array}$ \\
\hline & $\begin{array}{l}\text { Information } \\
\text { services }\end{array}$ & 0.001 & $\begin{array}{l}<0,05 ; \text { a significant difference between } \\
\text { information services and satisfaction }\end{array}$ \\
\hline & Membership & 0.000 & $\begin{array}{l}<0,05 ; \quad \text { a significant difference between } \\
\text { membership and satisfaction }\end{array}$ \\
\hline & $\begin{array}{l}\text { Premium paid, } \\
\text { information } \\
\text { services, and } \\
\text { membership* }\end{array}$ & 0.000 & $\begin{array}{l}<0,05 \text {; a significant difference between premium } \\
\text { paid, information services, and membership } \\
\text { simultaneously and satisfaction }\end{array}$ \\
\hline
\end{tabular}

*Multiple linear regression

Table IV. Effect of Pharmacy Services to Patient Satisfaction

\begin{tabular}{|c|c|c|c|}
\hline $\begin{array}{c}\text { Dependent } \\
\text { Variable }\end{array}$ & Independent Variable & $\mathrm{p}$ & Result \\
\hline \multirow{4}{*}{$\begin{array}{c}\text { Patient } \\
\text { Satisfaction }\end{array}$} & Drug availability & 0.003 & \multirow{4}{*}{$\begin{array}{l}<0,05 \text {; a significant difference between } \\
\text { drug availability and satisfaction } \\
<0,05 \text {; a significant difference between } \\
\text { service time and satisfaction } \\
<0,05 \text {; a significant difference between } \\
\text { drug information and satisfaction } \\
<0,05 \text {; a significant difference between } \\
\text { drug availability, service time, and drug } \\
\text { information simultaneously and } \\
\text { satisfaction }\end{array}$} \\
\hline & Service time & 0.006 & \\
\hline & Drug information & 0.000 & \\
\hline & $\begin{array}{c}\text { Drug availability, service } \\
\text { time, and drug } \\
\text { information* }\end{array}$ & 0.000 & \\
\hline
\end{tabular}

*Multiple linear regression 
According Mulupi et al.. (2013), fuzziness membership procedures and lack of information in accessing services influence decision of participants to take advantage of the health services available. According to data BPJS Kesehatan, some participants do not understand the procedures of participation as a membership registration, the registration form, and procedures for the use of membership cards during treatment at health facilities. This causes the participants were dissatisfied with the system used and can not take advantage of membership facilities.

\section{Effect Analysis of Pharmacy Services to Patient Satisfaction}

To see the effect of the pharmacy services to patient satisfaction used linear regression analysis. Pharmacy services said to have a significant effect on satisfaction if it has a sig (p) $<0.05$.

Public access to the drug is strongly influenced by the availability of drugs. Availability of complete curing will be easier for people to search for the necessary medication needs. Inventory drug will inhibit smooth health care, which would affect patient satisfaction and loyalty (Fakhriadi et al., 2011). Patients were satisfied with the availability of drugs in health centers and clinics pratama because getting needed medication as prescribed, although since the introduction of the system JKN number of drugs obtained fewer patients so that patients have to travel back and forth almost every week to obtain the drug.

According Harijono and Soepangkat (2011), the speed of service affects the patient's satisfaction and loyalty. Factors that may affect the service time is the number of patients who visit, the administration process flow, and limitations of medical personnel. If more patients come, the service more relatively slow. Service time will be longer if the health facility is not supported by appropriate medical personnel. This causes the patient satisfaction will vary depending on the readiness of each health facility to implement JKN system.

Drug information services are a provision of activities. The provision of drug information and recommendations are accurate, by the pharmacist to the patient. Provision of clear and complete information can affect patient satisfaction when receiving services (Trimurthy, 2008). According to the results of interviews with some of the respondents, the informations provided by the pharmacy personnel are easy to understand, include of the method of use, time of use, duration of use, storage, but to the information in the form of prohibitions or restrictions when drugs are rarely given. For general information about the patient, the service flow JKN generally well served.

\section{CONCLUSION}

There is the influence of patient characteristics include education, employment, income, and membership status on patient satisfaction. There is the influence of JKN services includes premium services, information services, and participation, either partially or simultaneously on patient satisfaction. There is the influence of pharmacy services includes drug availability, service time, and drug information, either partially or simultaneously on patient satisfaction.

\section{REFERENCES}

Agyei-Baffour P., Oppong R., and Boateng D., 2013. Knowledge, Perceptions And Expectations Of Capitation Payment System In A Health Insurance Setting: A Repeated Survey Of Clients And Health Providers In Kumasi, Ghana. Bmo Public Health, 13: 1220.

Akinci F., Sinay T., 2003. Perceived access in a managed care environment: determinants of satisfaction. Health Services Management Research, 16: 85-95.

Bauk I., Kadir AR., dan Saleh A., 2013. Hubungan Karakteristik Pasien Dengan Kualitas Pelayanan: Persepsi Pasien Pelayanan Rawat Inap RSUD Majene Tahun 2013. Jurnal Passcasarjana Universitas Hasanuddin, -: .

Budiman, Suhat, dan Herlina N., 2010. Hubungan Status Demografi Dengan Kepuasan Masyarakat Tentang Pelayanan Jamkesmas Di Wilayah Puskesmas Tanjungsari Kabupaten Bogor Tahun 2010. Jurnal Kesehatan Kartika, 27: . 
Fakhriadi A., Marchaban, dan Pudjaningsih, D. 2011. Analisis Pengelolaan Obat Di Instalasi Farmasi Rumah Sakit Pku Muhammadiyah Temanggung Tahun 2006, 2007 dan 2008. JMPF, Volume 2. No. 3

Hall JA. Dornan MC., 1990. Patient sociodemographic characteristics as predictors of satisfaction with medical care: A meta-analysis. Social Science \& Medicine, 30: 811-818.

Harijono H dan Soepangkat BO. 2011. Upaya Peningkatan Kualitas Layanan Farmasi RSK. ST VINCENTIUS A PAULO Surabaya Dengan Menggunakan Metode Servqual Dan QFD. Prosiding Seminar Nasional Manajemen Teknologi XIV Program Studi MMT-ITS, Surabaya 23 Juli 2011

Hidayati AN., Suryawati C., dan Sriatmi A., 2014. Analisis Hubungan Karakteristik Pasien dengan Kepuasan Pelayanan Rawat Jalan Semarang Eye Center (SEC) Rumah Sakit Islam Sultan Agung Semarang. Jurnal Kesehatan Masyarakat, Volume 2, Nomor 1, Januari 2014: .

Kotler P., Shalowitz J., and Stevens R., 2008. Strategic Marketing for Health Care Organizations: Building A Customer-Driven Health System. Jossey-Bass, San Francisco.

Manurung, LP., 2010. 'Analisis Hubungan Tingkat Kepuasan Pasien Rawat Jalan Terhadap Pelayanan Instalasi Farmasi Dengan Minat Pasien Menebus Kembali Resep Obat Di Instalasi Farmasi RSUD Budhi Asih Tahun 2010', Tesis, . MPh, Fakultas Kesehatan Masyarakat, Universitas Indonesia, Jakarta.
Mulupi S., Kirigia D., and Chuma J., 2013. Community perceptions of health insurance and their preferred design features: implications for the design of universal health coverage reforms in Kenya. BMC Health Services Research, 13: 474.

Notoatmodjo S., 2010. Ilmu Perilaku Kesehatan. Rineka Cipta, Jakarta.

Pohan IS., 2007. Jaminan Mutu Pelayanan Kesehatan Dasar-Dasar Pengertian Dan Penerapan. Penerbit Buku Kedokteran Egc.

Republik Indonesia, 2011. Undang-Undang Republik Indonesia, Nomor 24 Tabun 2011, Tentang Badan Penyelenggara Jaminan Sosial. Sekretariat Negara Republik Indonesia, Jakarta.

Schoenfelder T., Klewer J., and Kugler J., 2010. Factors Associated with Patient Satisfaction in Surgery: The Role of Patients' Perceptions of Received Care, Visit Characteristics, and Demographic Variables. Journal of Surgical Research, 164: e53-e59.

Sumaryanti S., 2000. Pemanfaatan Pelayanan Kesehatan Oleh Masyarakat di Puskesmas Di Kecamatan Selogiri Kabupaten Wonogiri. Jurnal Media Medika Muda, 131: .

Trimurthy, I., 2008. Analisis Hubungan Persepsi Pasien Tentang Mutu Pelayanan Dengan Minat Pemanfaatan Ulang Pelayanan Rawat Jalan Puskesmas Pandanaran Kota Semarang. (Tesis). Semarang. Universitas Diponegoro. 